\title{
ASYMMETRIC EXCHANGE RATE PASS-THROUGH IN U.S. IMPORTS OF COCOA
}

\author{
JEFF LUCKSTEAD* \\ Department of Agricultural Economics and Agribusiness, University of Arkansas, Fayetteville, Arkansas
}

\begin{abstract}
Both the autoregressive distributed lag (ARDL) and the nonlinear ARDL frameworks are applied to model U.S. imports of cocoa beans from Côte d'Ivoire, Ghana, and the Dominican Republic (more than $90 \%$ of U.S. cocoa imports originate from these three countries). The results provide evidence of nonlinear and asymmetric pass-through of exchange rates, regional quality difference, and imperfect competition in U.S. cocoa imports. Furthermore, a rise or fall in U.S. income leads to an increase or decrease in U.S. cocoa imports.
\end{abstract}

Keywords. Asymmetric exchange rate pass-through, NARDL, U.S. cocoa imports JEL Classifications. Q17, F14

\section{Introduction}

In many tropical countries, cocoa is an important cash crop worth about $\$ 98$ billion globally in 2016 (WorldAtlas, 2017). In the cocoa growing region of West Africa, cocoa exports account for $15 \%$ and $11 \%$ of gross domestic product (GDP) in Côte d'Ivoire and Ghana, respectively (Tsiboe et al., 2016). Although West Africa is the largest cocoa growing region in the world, accounting for approximately $70 \%$ of total cocoa exports, Central America and Asian countries also grow and export cocoa. According to the Food and Agriculture Organization of the United Nations (2017), the United States comprises 14.76\% of the global cocoa bean market with $\$ 1.137$ billion worth of imports. As seen in Table 1, between 2012 and 2016, U.S. cocoa imports primarily originate from Côte d'Ivoire (about 59\%) and Ghana (about 13\%) in West Africa, while Ecuador (about 16\%) and the Dominican Republic (about 5.5\%) in Central and South America are also important. Combined, the United States imports about $93 \%$ of all its cocoa beans from these four regions. Furthermore, Figure 1 shows total U.S. cocoa imports have grown from \$384 million in 1989 to \$1.294 million

The project was supported by the Agricultural and Food Research Initiative Competitive Program of the U.S. Department of Agriculture, National Institute of Food and Agriculture (grant number 201611898854).

*Corresponding author's e-mail: jluckste@uark.edu 
Table 1. U.S. Cocoa Imports (\%) by Country of Origin

\begin{tabular}{|c|c|c|c|c|c|}
\hline \multirow[b]{2}{*}{ Country } & \multicolumn{5}{|c|}{ Year } \\
\hline & 2012 & 2013 & 2014 & 2015 & 2016 \\
\hline Côte d'Ivoire & 57.941 & 59.479 & 57.327 & 54.069 & 64.455 \\
\hline Ghana & 12.499 & 13.393 & 12.003 & 13.898 & 14.014 \\
\hline Ecuador & 12.559 & 15.030 & 18.006 & 20.730 & 12.900 \\
\hline Dominican Republic & 7.750 & 4.822 & 5.284 & 5.617 & 3.995 \\
\hline Percent of total & 90.749 & 92.724 & 92.62 & 94.314 & 95.364 \\
\hline
\end{tabular}

Source: United Nations (2017).
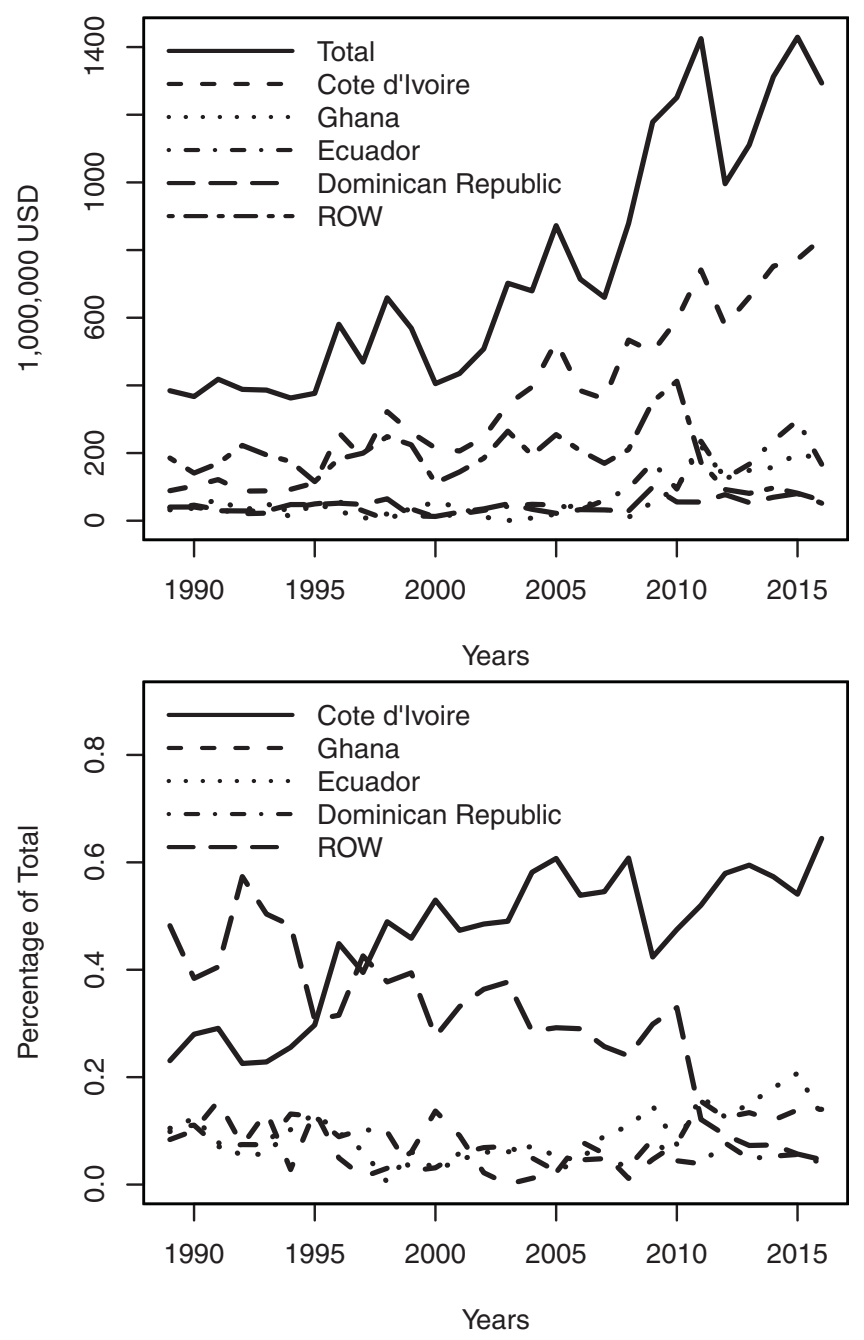

Figure 1. U.S. Cocoa Imports by Country of Origin (source: United Nations, 2017) 
in 2016, a 237\% increase. Also, the dominance of U.S. cocoa imports from Côte d'Ivoire has been steadily increasing since the mid-1990s.

With the majority of cocoa beans sold on the international market, exchange rate volatility is an important source of risk in international trade. Although, theoretically, appreciation or depreciation of an importer's currency causes a rise or fall in cocoa imports, the quantitative impact of this volatility on imports is largely unexplored in agricultural economics literature, particularly for cocoa. Furthermore, new advances in time-series econometrics allow researchers to explore the nonlinear and asymmetric pass-through of exchange rate volatility on trade volumes and prices. The short- and long-run impacts of currency fluctuations on cocoa trade volumes are important to policy makers, international risk managers, and firms downstream in the chocolate supply chain. This study quantifies the nonlinear and asymmetric pass-through of exchange rate volatility on U.S. imports of cocoa from Côte d'Ivoire, Ghana, and the Dominican Republic. In doing so, this analysis provides insight into potential imperfect competition in the international cocoa market, as, depending on elasticities, import volumes may be adjusted or maintained as exchange rates move to maximize returns.

The empirical trade literature on exchange rate pass-through has largely focused on the oil market. This literature finds evidence that pass-through of exchange rates and petroleum prices to the gasoline market are asymmetric and nonlinear (see Atil, Lahiani, and Nguyen, 2014; Bachmeier and Griffin, 2003; Bagnai and Ospina, 2015, 2016; Jammazi et al., 2015; Kilian, 2008). For a nonpetroleum analysis, Delatte and López-Villavicencio (2012) considered the short- and long-run asymmetric impacts of exchange rate volatility on consumer prices in developed countries using an autoregressive distributed lag (ARDL) model. A key finding is that consumer prices react asymmetrically to currency appreciation and depreciation. More recently, Fedoseeva and Zeidan (2016) employed a dynamic nonlinear cointegrating model to analyze asymmetry in European exports to Brazil, Russia, India, and China. Their results showed that, although exchange rates, relative prices, and foreign demand are key determinants of European exports to these countries, the effect of each of these explanatory variables changes depending on the country and industry. Studies analyzing nonlinear exchange rate pass-through have grown substantially in recent years (for papers reviewing this literature, see Burstein and Gopinath, 2013; Frey and Manera, 2007).

Several studies have analyzed symmetric pass-through of exchange rates to agricultural markets. This early literature found evidence of imperfect exchange rate pass-through in U.S. imports of tobacco from Brazil (Pompelli and Pick, 1990) and U.S. and Thai exports of rice (Yumkella, Unnevehr, and Garcia, 1994). More recently, Miljkovic, Brester, and Marsh (2003) found incomplete exchange rate pass-through for U.S. beef, pork, and poultry export prices for several countries. Miljkovic and Zhuang (2011) considered exchange rate pass-through 
for Japanese meat imports. Their results indicated partial pass-through for beef and poultry import prices, whereas the pork import price has zero exchange rate pass-through because of Japanese pork policies. Chen and Juvenal (2016) analyzed the response of heterogeneous Argentinean wine exporters to real exchange rate volatility resulting from differences in quality. Their results suggest that for higher-quality wine, exchange rate depreciation leads to a significant rise in the markup of the price and a fall in export volumes for wine exports to highincome countries.

There is scant agricultural trade literature analyzing nonlinear and asymmetric pass-through of exchange rates in agricultural markets. In a series of two papers, Fedoseeva $(2014,2016)$ has shown that exchange rate pass-through of European agrifood exports to the United States is highly nonlinear and asymmetric, indicating that euro depreciation benefits European Union (EU) exporters, whereas euro appreciation is detrimental to EU exporters. Fousekis and Trachanas (2016) found asymmetry in exogenous price stocks for major skim milk production in the United States, EU, and Oceania. Furthermore, their results showed higher price transmissions for negative prices shocks compared with positive price shocks. This paper is related to the work of Anders and Fedoseeva (2017), who analyze asymmetric exchange rate pass-through in coffee imports using a nonlinear autoregressive distributed lag (NARDL) model. Their results suggest that asymmetries in exchange rate pass-through depend on the country of origin, which suggests that the quality of coffee beans plays a strong role in determining imports.

This study contributes to the literature in two key ways: it provides (a) the first estimates of trade elasticities for U.S. imports of cocoa and (b) a detailed analysis of the asymmetric and nonlinear pass-through of exchange rate in cocoa markets, which has been largely ignored in the agricultural trade literature. Given the extent to which cocoa is used in processed food items, the understanding of the behavior of trading partners to market shocks is vitally important for policy makers and cocoa processors.

\section{Exchange Rates and Cocoa Markets}

This section provides a detailed discussion of exchange rates and cocoa markets for key U.S. cocoa trading partners. This study focuses on U.S. cocoa imports from Côte d'Ivoire, Ghana, and the Dominican Republic, which together account for more than $90 \%$ of all U.S. cocoa imports. Although Ecuador is the thirdlargest exporter of cocoa to the United States, the Ecuadorian government abandoned the sucre in 2000 and started using the U.S. dollar (USD) as their currency (Wang, 2016). Consequently, it is not possible to analyze exchange rate pass-through for U.S. cocoa imports from Ecuador.

Côte d'Ivoire's currency is the West African CAF franc (XOF), which was pegged to the euro on January 1, 1999, at a rate of 655.957 XOF per euro 
(OANDA, 2017). Therefore, volatility in the XOF is highly correlated to the euro. ${ }^{1}$ The Ghanaian currency, the cedi (GHS), was pegged to the USD in the 1970s and 1980s. However, with high inflation and dwindling currency reserves, the government converted to a floating exchange rate system starting in 1990 (Ameyibor, 2016). The Dominican peso (DOP) was fixed to the USD until 1985, when the government switched to a floating exchange rate system.

The global chocolate market grew by $13 \%$ from 2010 to 2015 to top $\$ 101$ billion (Barnato and Graham, 2016), which is important for the cocoa industry as cocoa beans are the primary input for chocolate production. Two types of cocoa (Forastero and Crillo) $^{2}$ are grown throughout the world (World Agroforestry Centre [ICRAF], 2017). The Forastero variety is most widely grown in West Africa, Brazil, and Southeast Asian countries, whereas Crillo is grown primarily in the Caribbean, Central and South America, and Indonesia. The majority of mass-production chocolate processors utilize the high-yield, lower-quality Forastero bean (85\% of all cocoa production), whereas specialty chocolate processors use the low-yield, higher-quality Crillo bean (about $3 \%$ of total cocoa production).

The World Bank and International Monetary Fund required cocoa-producing countries in West Africa to institute structural adjustment programs (SAPs) in the mid-1980s (Gilbert, 2009). The SAPs aimed to improve the linkage between world cocoa prices and cocoa farmers. The Ivorian government implemented SAP between 1998 and 2002, and Ghana partially liberalized its cocoa sector between 1992 and 1993. In Côte d'Ivoire, the Coffee and Cocoa Council still oversees the cocoa market, but charges high export taxes, offers low farm-gate prices, and provides few extension services (Ton et al., 2008). Furthermore, the government loosened its oversight of cocoa the early 1990s, giving private parties the ability to control credit, pricing, and export license. Despite being the largest cocoa-exporting country, Ivorian cocoa farmers still lack sufficient information regarding markets and quality requirements and pay high transport costs (Tsiboe et al., 2016). The Ghanaian cocoa export market is still controlled by the Ghanaian Cocoa Marketing Board, which is the sole buyer of cocoa from farmers, controls all exports, provides farmers with reduced farm-gate prices, ${ }^{3}$ but does offer some services such as farmer training, input subsidies, and seed distribution (Gilbert, 2009; Ton et al., 2008; Tsiboe et al., 2016). SAPs have led to better-functioning markets and higher farm-gate prices for cocoa producers; however, privatization has resulted in a reduction in extension services, agricultural research, and rural banking. Consequently, African cocoa producers have particularly low yields, quality, and prices relative

1 The correlation between the USD/euro and the USD/XOF exchange rates is 0.78 (U.S. Department of Agriculture, Economic Research Service, 2017).

2 Trinitario is considered a third variety, but it is a hybrid of Forastero and Crillo.

3 For 2010-2013, farmers received about $78 \%$ of the net free-on-board price. 
to their American and Southeast Asian counterparts (Nyemeck, Gockowski, and Nkamleu, 2007; Tsiboe et al., 2016; Wilcox and Abbott, 2006).

In contrast to the African system, the Dominican government has largely stayed out of its cocoa market (Estrella, 2016). The government established the Department of Cocoa in early 2014, which operates as an "autonomous and decentralized state" agency commissioned to protect the interest of the cocoa industry. The Department of Cocoa largely acts as a service agency, assisting with crop development, infrastructure, marketing, market expansion, and diversification.

In summary, Côte d'Ivoire's cocoa industry is a mix of public and private entities governing the cocoa sector. However, in Ghana the government is directly involved in setting prices and exporting cocoa. In contrast, the Dominican cocoa industry is market based, with the government mainly providing extension and marketing services. The regional difference in cocoa bean type and quality and the degree to which government agencies control exports (particularly in Ghana) play an important role in (a) how cocoa exporters respond to exchange rate volatility and (b) the degree of asymmetry in exchange rate pass-through.

\section{Econometric Model}

Next, the model for estimating the short- and long-run relationship between U.S. cocoa imports and exchange rates and per capita income is discussed in detail. To ensure that these variables have a genuine causal relationship, a test for cointegration ${ }^{4}$ between volume of real U.S. cocoa imports (in USD) with the real exchange rate (USD/local currency units [LCU]) and U.S. domestic demand measured in real per capita income is considered (Engle and Granger, 1987; Johansen, 1988; Nelson and Plosser, 1982). Accordingly, the ARDL ${ }^{5}$ model (Pesaran and Shin, 1998) is defined as

$$
\begin{aligned}
\Delta m_{t}^{k}= & \alpha^{k}+\beta^{k} m_{t-1}^{k}+\psi_{r}^{k} r_{t-1}^{k}+\psi_{i}^{k} i_{t-1} \\
& +\sum_{n=1}^{N} \phi_{n}^{k} \Delta m_{t-n}^{k}+\sum_{n=1}^{N}\left(\rho_{r, n}^{k} \Delta r_{t-n}^{k}+\rho_{i, n}^{k} \Delta i_{t-n}\right)+\xi_{t}^{k},
\end{aligned}
$$

where $\alpha^{k}, \beta^{k}, \psi_{r}^{k}, \psi_{i}^{k}, \phi_{n}^{k}, \rho_{r, n}^{k}$, and $\rho_{i, n}^{k}$ are coefficients; the $k$ superscript represents country $k=$ Côte d'Ivoire, Ghana, and Dominican Republic; $\Delta$ defines the first difference; $m_{t}^{k}$ is the log of the real value of U.S. cocoa imports from country $k ; r_{t}^{k}$ is the log of the real exchange rate (LCU/USD) for country $k ; i_{t}$ is the log of real

4 Cointegrating occurs when two or more time series are individually integrated and a linear combination is of a lower order of integration. For example, if $A$ and $B$ are both integrated of order $1[I(1)]$ and coefficients $\alpha$ and $\beta$ exist such that $\alpha A+\beta B$ is integrated of order $0[I(0)]$, then $A$ and $B$ are cointegrated. Cointegration is important because it implies a causal relationship between variables $A$ and $B$.

5 The ARDL model is closely related, but preferred, to the error correction model because of its flexibility to define nonlinear relationships. 
per capita income representing U.S. domestic demand; and $\xi_{t}^{k}$ is a random error term. Analysts commonly apply Akaike information criterion and Bayesian information criterion to determine the lag order N. Equation (1) represents three independent regression equations, one for each country $k$. As a result, trade elasticities and asymmetry tests (defined subsequently) can be compared across countries.

The error correction term $\beta^{k} \in[-1,0]$ is key for expressing long-run relationships: if $\beta^{k}=-1$, then instantaneous long-run equilibrium adjustments occur; conversely, if $\beta^{k}=0$, then no long-run relationship exists between U.S. cocoa imports and USD/LCU exchange rates and income. In addition, if $\beta^{k}=$ 0 , then the model only estimates short-term dynamics, and no cointegration relationships exist. In the ARDL specification, the coefficients $\psi_{r}^{k}$ and $\psi_{i}^{k}$ are the product of the long-run elasticities $\left(e_{r}^{k}\right.$ and $\left.e_{i}^{k}\right)$ and the error correction term $\left(\beta^{k}\right)$. Therefore, the long-run exchange rate and income pass-through elasticities ${ }^{6}$ are

$$
e_{r}^{k}=-\frac{\psi_{r}^{k}}{\beta^{k}} \quad \text { and } \quad e_{i}^{k}=-\frac{\psi_{i}^{k}}{\beta^{k}}
$$

Parameters $\phi_{n}^{k}$ and $\rho_{r, n}^{k}$ and $\rho_{r, n}^{k}$ characterize the short-term dynamics, with $\rho_{r, 0}^{k}$ and $\rho_{i, 0}^{k}$ representing the contemporaneous elasticities of exchange rates and import demand on trade volumes.

To investigate asymmetric reactions of U.S. cocoa imports to changes in exchange rates, the NARDL approach, along with a partial sum decomposition of the explanatory variable, is implemented (Shin, Yu, and GreenwoodNimmo, 2014). In doing so, cutting-edge econometric techniques are applied to investigate the existence of short- and long-run asymmetries and test for hidden cointegration, which is not possible using the standard error-correlation or ARDL model. The partial sum decomposition for exchange rate $r_{t}$ is

$$
r_{t}^{k}=r_{0}^{k}+r_{t}^{k-}+r_{t}^{k+}
$$

where $r_{0}$ is the initial value at $t_{0}$, and the negative and positive first-difference partial sums are

$$
r_{t}^{k-}=\sum_{n=1}^{t} \min \left(\Delta r_{n}^{k}, 0\right) \quad \text { and } \quad r_{t}^{k+}=\sum_{n=1}^{t} \max \left(\Delta r_{n}^{k}, 0\right) .
$$

Substituting the partial sum decomposition of exchange rates (equation 2) into the ARDL model (equation 1) yields the NARDL model:

$$
\begin{aligned}
\Delta m_{t}^{k}= & \alpha_{0}^{k}+\beta^{k} m_{t-1}^{k}+\psi_{r}^{k-} r_{t-1}^{k-}+\psi_{r}^{k+} r_{t-1}^{k+}+\psi_{i}^{k} i_{t-1}+\sum_{n=1}^{N} \phi_{n}^{k} \Delta m_{t-n}^{k} \\
& +\sum_{n=1}^{N}\left(\rho_{r, n}^{k-} \Delta r_{t-n}^{k-}+\rho_{r, n}^{k+} \Delta r_{t-n}^{k+}+\rho_{i, n}^{k} \Delta i_{t-n}\right)+\xi_{t}^{k}
\end{aligned}
$$

6 The Delta method is applied to obtain standard errors for these elasticities. 
Table 2. Summary Statistics

\begin{tabular}{|c|c|c|c|c|c|c|}
\hline & Mean & Median & Minimum & Maximum & $\begin{array}{l}\text { Standard } \\
\text { Deviation }\end{array}$ & Observations \\
\hline \multicolumn{7}{|l|}{ Imports } \\
\hline Côte d'Ivoire & $66,606.06$ & $64,155.21$ & 3.97 & $182,730.08$ & $28,907.40$ & 336 \\
\hline Ghana & $8,269.38$ & $5,894.92$ & 0.22 & $49,773.62$ & $7,165.75$ & 336 \\
\hline Dominican Republic & $6,789.83$ & $6,451.70$ & 0.31 & $17,914.57$ & $2,630.16$ & 336 \\
\hline \multicolumn{7}{|l|}{ Exchange rate } \\
\hline Côte d'Ivoire & 538.44 & 525.48 & 352.30 & 811.53 & 103.18 & 336 \\
\hline Ghana & 1.49 & 1.45 & 0.87 & 2.63 & 0.40 & 336 \\
\hline Dominican Republic & 41.38 & 40.18 & 35.57 & 66.11 & 5.03 & 336 \\
\hline USD GDP & $44,139.34$ & $44,967.00$ & $35,145.00$ & $51,849.00$ & $5,316.58$ & 336 \\
\hline
\end{tabular}

Note: USD GDP, gross domestic product in U.S. dollars.

where $\alpha_{0}^{k}=\alpha^{k}+r_{0}^{k}+i_{0}^{k}$. Similar to the previous discussion, the asymmetric longrun elasticities for the real exchange rate are

$$
e_{r}^{k-}=-\frac{\psi_{r}^{k-}}{\beta^{k}} \quad \text { and } \quad e_{r}^{k+}=-\frac{\psi_{r}^{k+}}{\beta^{k}} .
$$

\section{Data}

For the econometric analysis, the monthly value of U.S. imports from Côte d'Ivoire, Ghana, and the Dominican Republic for HS Code 180100 Cocoa Beans was obtained from the United Nations (2017) for the years 1989-2016. As identified in Section 2, more than $90 \%$ of all U.S. cocoa imports originate from these three countries. Nominal values were converted into real terms using the U.S. import deflator collected from the U.S. Department of Labor, Bureau of Labor Statistics (2017). Real import values were seasonally adjusted ${ }^{7}$ to account for seasonal trends and differences in harvest times across regions. Data for real LCU/USD were gathered from the U.S. Department of Agriculture, Economic Research Service (2017). Real per capita GDP was assembled from the Federal Reserve Bank of St. Louis (2017). Table 2 provides summary statistics of the import and exchange rate data for Côte d'Ivoire, Ghana, and the Dominican Republic and GDP data for the United States.

Figure 2 graphs the logged exchange rate data for each country and the corresponding partial sum decomposition. In Côte d'Ivoire, prior to the start of the 1995 cocoa sector liberalization, the exchange rate increased rapidly from a $\operatorname{low}$ of $\log (352.30)=5.86$ in August of 1992 to a peak of $\log (807.05)=$ 6.69 in January of 1995, indicating swift depreciation of the XOF (conversely,

7 Seasonal adjustments were made using the "stl" function in R, which decomposes the import data into seasonal, trend, and error components using LOESS (Local regression). 
Cote d'Ivoire

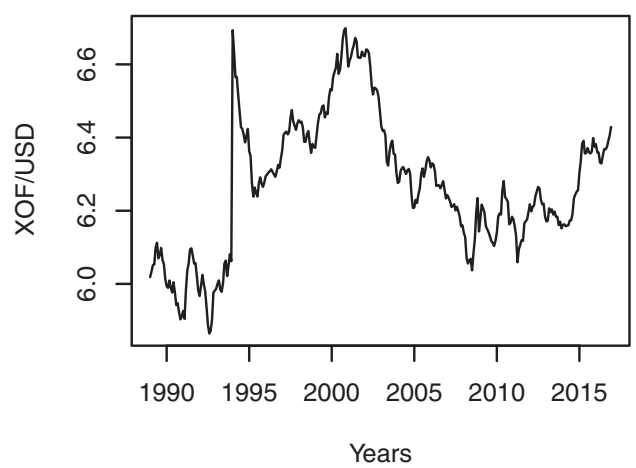

Ghana

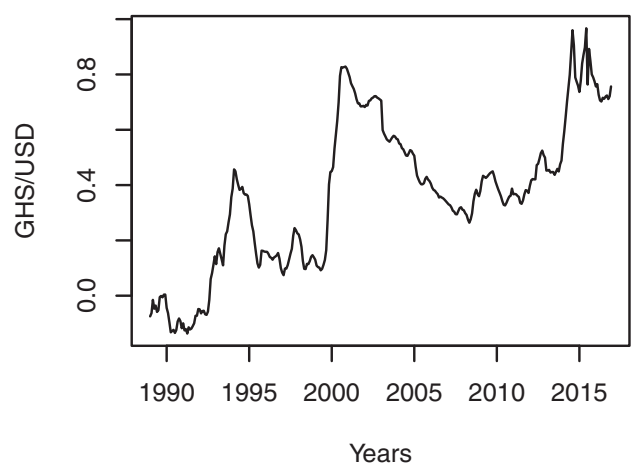

Dominican Republic

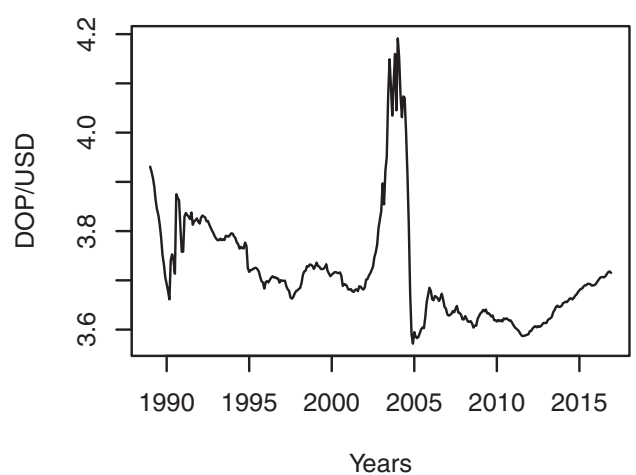

Cote d'Ivoire

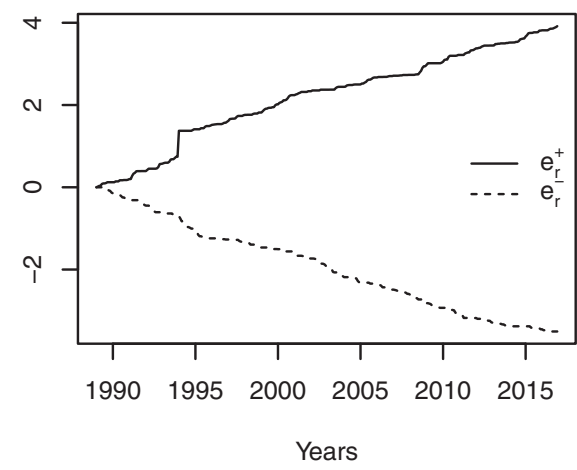

Ghana

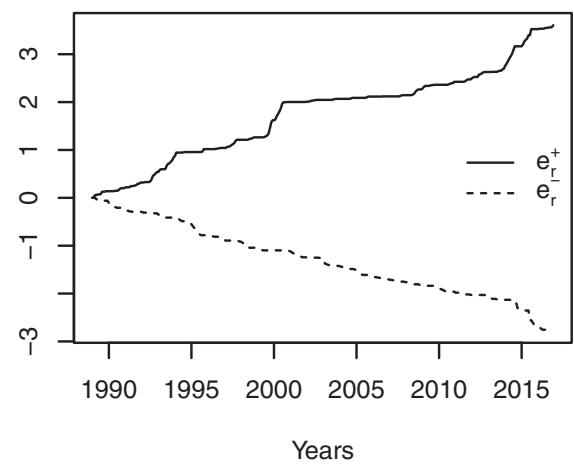

Dominican Republic

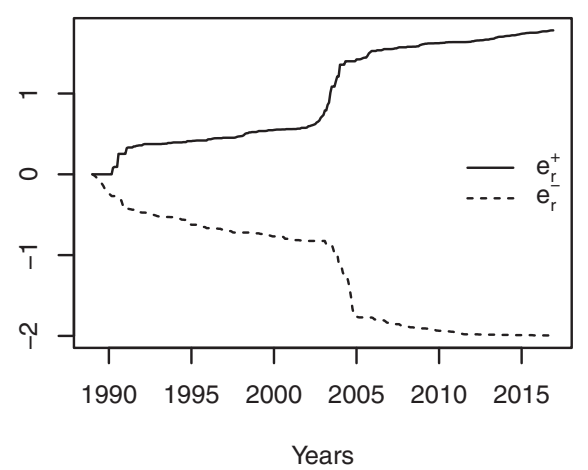

Figure 2. Exchange Rates and Their Partial Sum Decomposition 


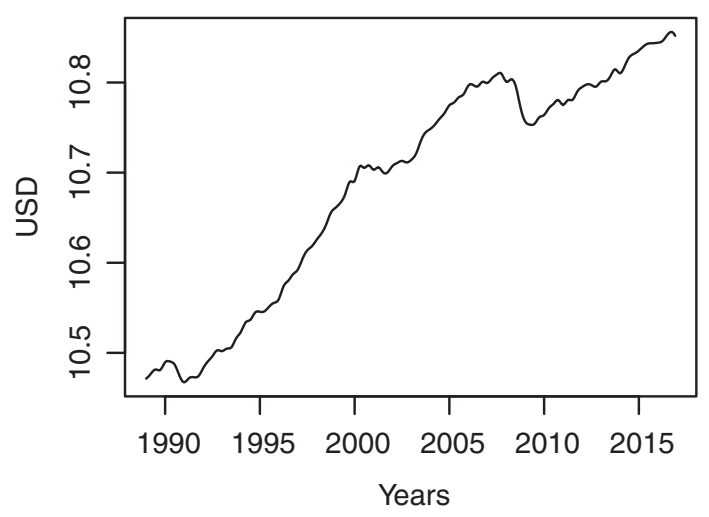

Figure 3. Log Real Gross Domestic Product per Capita

appreciation of the USD). This depreciation is seen by the spike in the $e_{r}^{k+}$ partial sum decomposition. Since this event, the Ivorian exchange rate has been fairly volatile with periods of depreciation from about 1995 to 2002 followed by appreciation from about 2002 to 2012. For Ghana, two periods of rapid depreciation of the GHS stand out. The first occurred starting in the late 1990s through the early 2000 s when the exchange rate rose from $\log (1.102)=0.10$ in June 1999 to $\log (2.286)=0.83$ in October 2000. The second started in the mid-2010s when the exchange rate rose from $\log (1.548)=0.44$ in July 2013 to $\log (2.612)=0.96$ in August 2014. Both of these episodes of rapid depreciation are seen as spikes in the $e_{r}^{k+}$ partial sum decomposition. For the Dominican Republic, the economic crisis of 2003 and 2004, largely attributed to a failed bank bailout, led to a rapid depreciation of the DOP as the exchange rate increased from $\log (39.576)=3.68$ in December 2001 to $\log (64.113)=4.16$ in November 2003. The resolution of this crisis resulted in a rapid appreciation as the exchange rate fell to $\log (35.434)=3.57$ by March 2005 . The rapid depreciation and appreciation are readily seen in the $e_{r}^{k+}$ and $e_{r}^{k-}$ partial sum decompositions. These depreciation and appreciation events are used to create indicator variables, which are included in the analysis where appropriate.

Figure 3 depicts the log of real U.S. GDP per capita. The three recessions since the late 1980s (July 1990-March 1991, resulting from heightened inflation and 1990 oil price shock; March 2001-November 2001, caused by the collapse of the dot-com bubble; and the great recession, December 2007-June 2009, resulting from the collapse of the housing bubble) are readily observed in the log real GDP per capita data.

\section{Results}

This section analyzes the pass-through effects and cointegration of exchange rates and income. Pass-through of exchange rates and income are examined by 
implementing two models. The first model is the standard ARDL model with no asymmetries. The second model is the NARDL model with asymmetries modeled as partial sum decomposition in exchange rates. This section also reports the results of statistical tests for asymmetric responses in the pass-through effects for the NARDL model.

\subsection{Pass-Through Effects (Long-Run Elasticities) and Cointegration}

Here, the pass-through effects for the two models (ARDL and NARDL) for U.S. imports of cocoa from Côte d'Ivoire, Ghana, and the Dominican Republic are examined. The full estimation results along with diagnostic tests for the two models are presented in the supplementary online appendix (Tables A1 and A2). The adjusted $R^{2}$ ranges from 0.62 to 0.91 and is higher for Côte d'Ivoire and Ghana than for the Dominican Republic for both models, which can be an indication of quality differences in West African versus Caribbean cocoa. For each country and model, standard diagnostic tests (the Breusch-Godfrey test, the Ramsey RESET test, and the Jarque-Bera test for normality) indicate stability in the regressions and normally distributed residuals without serial correlation.

To rule out spurious relationships between the real value of U.S. cocoa imports and real exchange rates and real per capita income, the bounds testing approach for cointegration, developed by Pesaran, Shin, and Smith (2001), is implemented. ${ }^{8}$ The results indicate strong evidence of cointegration for the three variables for all three regions and both models (see Table 3, third column, for each country designation), which implies meaningful inference on the passthrough relationship in exchange rates and income to trade flows can be drawn from the dynamic estimates of U.S. sourcing of cocoa. Although cointegration holds in all three regions, regional differences exist as the results for cointegration are strongest for Côte d'Ivoire ( $F$-statistic of 895 for model 1 and 868 for model 2), followed by Ghana (F-statistic of 302 for model 1 and 338 for model 2) and the Dominican Republic (F-statistic of 90 for model 1 and 89 for model 2 ). The regional differences occur because the lower quality of the Forastero cocoa bean, used for mass production, is largely grown in West Africa, whereas the high-quality Crillo cocoa bean, used for specialty chocolate, is primarily grown in South America and the Caribbean (ICRAF, 2017). Furthermore, Côte d'Ivoire and Ghana combined produce about $2 \%$ of all organic cocoa, whereas the Dominican Republic produces about $70 \%$ of all organic cocoa (Potts et al., 2014), which further differentiates the cocoa beans grown in the two regions.

Long-run exchange rate elasticities and their corresponding $P$ values (first and second column for each country designation) are reported in Table 3 . These

8 To implement the bounds testing approach, test if the coefficients of two variables (e.g., $\beta$ and $\psi_{r}$ ) are simultaneously zero using a Wald test. If the $F$ value of the Wald test is outside of the critical bounds as specified in Pesaran, Shin, and Smith (2001), then the two variables are cointegrated and inference about the long-run relationship between the two variables can be drawn. 
Table 3. Long-Run Cocoa Import Elasticities and Cointegration

\begin{tabular}{|c|c|c|c|c|c|c|c|c|c|}
\hline & \multicolumn{6}{|c|}{ Africa } & \multirow{2}{*}{\multicolumn{3}{|c|}{$\begin{array}{c}\text { Caribbean } \\
\text { Dominican Republic }\end{array}$}} \\
\hline & \multicolumn{3}{|c|}{ Côte d'Ivoire } & \multicolumn{3}{|c|}{ Ghana } & & & \\
\hline & Elasticity & $P$ & $F$-statistic ${ }^{\mathrm{a}}$ & Elasticity & $P$ & $F$-statistic ${ }^{a}$ & Elasticity & $P$ & $F$-statistic ${ }^{\mathrm{a}}$ \\
\hline \multicolumn{10}{|l|}{ Model 1: ARDL } \\
\hline ER & 0.03 & 0.71 & 894.66 & 0.27 & 0.15 & 301.71 & 0.70 & 0.34 & 90.36 \\
\hline GDP & 1.05 & 0.00 & 894.54 & 0.19 & 0.64 & 301.74 & 1.39 & 0.01 & 90.36 \\
\hline \multicolumn{10}{|l|}{ Model 2: NARDL } \\
\hline $\mathrm{ER}^{-}$ & 7.03 & 0.00 & 868.31 & -16.60 & 0.00 & 337.77 & 1.19 & 0.83 & 88.77 \\
\hline $\mathrm{ER}^{+}$ & -0.17 & 0.89 & 865.31 & 10.70 & 0.00 & 337.95 & 12.01 & 0.06 & 88.88 \\
\hline GDP & 0.87 & 0.00 & 864.77 & 0.55 & 0.02 & 337.79 & 1.17 & 0.01 & 88.78 \\
\hline
\end{tabular}

${ }^{a} F$-statistic for bounds testing approach for cointegration. Critical values of $5 \%=3.24$ and $1 \%=3.86$ are from Pesaran, Shin, and Smith (2001).

Notes: ARDL, autoregressive distributed lag; ER, exchange rate; $\mathrm{ER}^{-}$and $\mathrm{ER}^{+}$, negative and positive firstdifference exchange rate, respectively; GDP, gross domestic product; NARDL, nonlinear autoregressive distributed lag.

elasticities generally conform to theoretical expectations: appreciation (increase in LCU/USD) leads to a rise in U.S. cocoa imports because 1 USD purchases more LCU and thus more cocoa. By contrast, depreciation (decrease in LCU/USD) leads to a fall in U.S. cocoa imports because 1 USD purchases fewer LCU and thus less cocoa. For the ARDL model, the elasticities are inelastic and range from 0.03 to 0.70 , albeit none are statistically significant. These elasticities indicate that a $1 \%$ increase in the exchange rate leads to a $0.03 \%, 0.27 \%$, and $0.70 \%$ rise in U.S. imports of cocoa from Côte d'Ivoire, Ghana, and the Dominican Republic, respectively. With respect to income, the elasticities are both inelastic and elastic. For Côte d'Ivoire and the Dominican Republic, the income elasticities are elastic and highly significant at 1.05 and 1.39 , respectively; whereas, in Ghana, the income elasticity is inelastic and insignificant at 0.64 . Thus, a $1 \%$ rise in income leads to a $1.05 \%, 0.64 \%$, and $1.39 \%$ increase in cocoa imports from Côte d'Ivoire, Ghana, and the Dominican Republic, respectively. These elasticities show that the high-quality beans grown in the Dominican Republic are more responsive to improved demand conditions than the low-quality beans grown in Côte d'Ivoire and Ghana.

The importance of accounting for asymmetric pass-through is readily seen by analyzing the results of the NARDL model. For Côte d'Ivoire, the longrun import elasticity with respect to USD depreciation $\left(\mathrm{ER}^{-}\right)$is elastic at 7.03, which implies that a $1 \%$ depreciation in the USD leads to a $7.03 \%$ decline in imports. This elasticity implies that U.S. importers can easily substitute away from cocoa produced in Côte d'Ivoire when the USD depreciates. On the other hand, dollar appreciation is highly insignificant, suggesting that U.S. cocoa importers do not necessarily import more Ivorian cocoa when the USD 
appreciates. Consequently, U.S. cocoa importers show asymmetric responses to USD appreciation and depreciation when importing cocoa from Côte d'Ivoire. This behavior is consistent with the fact that Ivorian cocoa beans are low quality, and extension services to assist Ivorian farmers in standard cultivation practices and promote their product internationally do not exist. With the inclusion of nonlinear pass-through in exchange rates, the income elasticity declines from 1.05 in model 1 to 0.87 in model 2 and is statistically significant. This result implies that imports become less responsive to demand shocks when exchange rate asymmetries are included in the model.

For Ghana, the results for asymmetric exchange rate elasticities provide insight into the behavior of the Ghanaian Cocoa Marketing Board. As is theoretically expected, with an elasticity of 10.70 , U.S. cocoa imports from Ghana are highly elastic with respect to USD appreciation; a $1 \%$ appreciation in the USD leads to a $10.70 \%$ increase in U.S. imports. However, as the USD depreciates, U.S. imports from Ghana also rise. Not only is this increase in imports highly elastic (16.60), but it is also statistically significant. These results suggest that the Ghanaian Cocoa Marketing Board-the sole exporter of Ghanaian cocoa-does not respond to USD depreciation as would be predicted by economic theory. The board is implementing export expansion policies during times of USD depreciation to maintain a strong cocoa trade relationship with the U.S. cocoa importers. Therefore, the marketing board is more concerned with promoting export growth as opposed to maximizing LCU returns when USD depreciation occurs. Allowing for asymmetric exchange rate response results in the income elasticity increasing from an statistically insignificant level of 0.19 in model 1 to a significant level of 0.55 in model 2 . Consequently, imports are more responsive to income shocks in the NARDL model.

In the Dominican Republic, the empirical results are consistent with theoretical predictions. Interestingly, although dollar depreciation does lead to a decline in cocoa imports from the Dominican Republic, the elasticity is barely elastic at 1.19 and highly insignificant. As a result, U.S. imports of Dominican cocoa are not responsive to dollar depreciation. On the other hand, U.S. imports of Dominican cocoa are highly responsive to dollar appreciation; the elasticity is 12.01 and statistically significant. These results imply that, because the Crillo variety and organic cocoa is relatively unique to the Dominican Republic, U.S. importers have few alternative countries from which to import the Crillo variety or organic cocoa as the USD depreciates. Consequently, as the USD depreciates and Dominican cocoa becomes more expensive, U.S. cocoa import volumes are unchanged, statistically speaking. The income elasticity falls from 1.39 in the ARDL model to 1.17 in the NARDL model and is statistically significant in both cases.

\subsection{Testing for Asymmetry in Pass-Through Effects}

Next, the existence of two different types of asymmetric adjustments for the partial sum decomposition terms in the NARDL model is analyzed. First, 
Table 4. Test for Asymmetry

\begin{tabular}{clll}
\hline \hline & \multicolumn{2}{c}{ Africa } & Caribbean \\
\cline { 2 - 3 } & Côte d'Ivoire & Ghana & Dominican Republic \\
\hline Model 2, $\mathrm{H}_{0}$ & & & \\
$\psi_{r}^{-}=\psi_{r}^{+}$ & 0.00 & 0.00 & 0.19 \\
$\rho_{r, 1}^{-}=\rho_{r, 1}^{+}$ & 0.01 & 0.00 & 0.86 \\
$\rho_{r, 2}^{-}=\rho_{r, 2}^{+}$ & 0.13 & 0.53 & 0.47 \\
$\rho_{r, 3}^{-}=\rho_{r, 3}^{+}$ & 0.14 & 0.18 & 0.59 \\
$\rho_{r, 4}^{-}=\rho_{r, 4}^{+}$ & 0.41 & 0.43 & 0.42 \\
$\rho_{r, 5}^{-}=\rho_{r, 5}^{+}$ & 0.00 & 0.76 & 0.41 \\
\hline \hline
\end{tabular}

inequality between the long-run coefficients for the real exchange rate $\left(\psi_{r}^{k-}\right.$ and $\psi_{r}^{k+}$ ) implies an asymmetric reaction in cocoa imports. The presence of asymmetry between the long-run coefficients for the negative or positive partial sums of the real exchange rate is examined by analyzing the hypothesis test that the coefficients are equal: $\mathrm{H}_{0}: \psi_{r}^{k-}=\psi_{r}^{k+}$. Second, inequality between the short-run coefficients for the real exchange rate $\left(\rho_{r, n}^{k-}\right.$ and $\left.\rho_{r, n}^{k+}\right)$ indicates an asymmetric reaction in cocoa imports resulting from contemporaneous effects. Testing for short-term asymmetry is analyzed via the following hypothesis test: $\mathrm{H}_{0}: \rho_{r, n}^{k-}=\rho_{r, n}^{k+}$ for $n=1, \ldots, N$. Failing to reject one of the hypotheses implies a symmetric relationship in that variable, whereas rejecting a hypothesis indicates an asymmetric relationship.

Table 4 reports the results of the tests for asymmetry. The results for the test for long-run asymmetry are reported in the first row: For Côte d'Ivoire and Ghana, the null hypothesis is rejected in favor of the alternate with a $P$ value of less than 0.00 , providing strong evidence of an asymmetric relationship in long-run exchange rate pass-through. However, for the Dominican Republic, the model fails to reject the null hypothesis at the $10 \%$ level, and the long-run pass-through effect is symmetric.

The results for the test for symmetry in the contemporaneous terms are reported in rows 2-6: For both Côte d'Ivoire and Ghana, asymmetries also exist for the contemporaneous effects for $\mathrm{n}=1$ (as well as for $\mathrm{n}=5$ for Côte d'Ivoire). However, consistent with the long-run effect, no statistically significant asymmetric relationships exist for the contemporaneous effects for the Dominican Republic. These results further support the observation of regional differences in West African versus Dominican cocoa.

\section{Conclusion and Discussion}

The empirical trade literature has seen a renewed interest in modeling the fluctuations in macroeconomic factors (e.g., exchange rates and incomes) on 
bilateral trade flows in both the short and long run because of new empirical methods to analyze asymmetric response. With its primary focus on oil markets, there are few studies analyzing nonlinear and asymmetric pass-through of exchange rates in agricultural markets. However, understanding how agricultural commodities respond to volatility in exchange rates and incomes is important for policy makers and industry leaders. This study contributes to the agricultural trade literature by analyzing the nonlinear exchange rate pass-through in U.S. imports of cocoa, a high-value agricultural market. Consequently, the results are of interest to not only the U.S. chocolate industry, but also developing countries in West Africa and the Caribbean.

This study applies both the ARDL and the recently developed NARDL frameworks to model U.S. imports of cocoa beans from Côte d'Ivoire, Ghana, and the Dominican Republic. Côte d'Ivoire and Ghana primarily grow the low-quality Forastero cocoa variety. With minimal extension services, these two countries, particularly Côte d'Ivoire, have struggled to meet the quality expectation of importers. Although Côte d'Ivoire does not have a state agency controlling cocoa exports, the Ghanaian Cocoa Marketing Board is the sole exporter of cocoa in Ghana. The Dominican Republic primarily grows the highquality Crillo cocoa variety and accounts for more than $70 \%$ of the organic cocoa market. The Dominican government plays no role in the export of cocoa beans and primarily provides extension and marketing services.

The results show substantial differences in U.S. trade partner behavior in response to exchange rate volatility. The results for the ARDL are consistent with trade theory-appreciation of the USD against local currency leads to more cocoa imports-however, the long-run trade elasticities are statistically insignificant for all three regions. The long-run income elasticities are theoretically consistent-a rise in income leads to an increase in trade volumes. However, the results for the NARDL model provide evidence of substantial asymmetry in the response of cocoa trade volumes to exchange rate volatility. For Côte d'Ivoire, while USD depreciation leads to a fall in U.S. import, appreciation does not necessarily lead to a rise in imports. This result is likely attributable to the particularly low quality of Ivorian cocoa as U.S. cocoa importers can look for other sources of Forastero cocoa. Interestingly, for Ghana, both USD appreciation and depreciation lead to a rise in U.S. cocoa imports from Ghana. This result provides strong evidence that the Ghanaian Cocoa Marketing Board implements cocoa export expansion policies to promote Ghanaian cocoa, particularly when the USD depreciates and exports should fall. For the Dominican Republic, USD appreciation results in an increase in U.S. imports of Dominican cocoa. However, USD depreciation does not necessarily lead to a fall in imports. This result indicates that, given the contiguous location and higher quality of the Dominican cocoa beans, U.S. importers have few viable options to import the Crillo cocoa variety when the USD depreciates. Taken together, these results provide evidence of imperfect competition in U.S. cocoa imports. Establishing additional source 
countries for cocoa could help bring more competition in the U.S. bilateral cocoa trade.

\section{Supplementary material}

To view supplementary material for this article, please visit https://doi.org/10. 1017/aae.2018.1

\section{References}

Ameyibor, F. "Currency Devaluation Is Not the Way Forward for Ghana." Ghana Business News. January 27, 2016. Internet site: https://www.ghanabusinessnews.com/2016/01/ 27/152901/ (Accessed July 19, 2017).

Anders, S., and S. Fedoseeva. "Quality, Sourcing, and Asymmetric Exchange-Rate PassThrough into U.S. Coffee Imports." Journal of Agricultural and Resource Economics 42,3(2017):372-85.

Atil, A., A. Lahiani, and D.K. Nguyen. "Asymmetric and Nonlinear Pass-Through of Crude Oil Prices to Gasoline and Natural Gas Prices.” Energy Policy 65( February 2014):567-73.

Bachmeier, L.J., and J.M. Griffin. "New Evidence on Asymmetric Gasoline Price Responses." Review of Economics and Statistics 85,3(2003):772-76.

Bagnai, A., and C.A.M. Ospina. "Long- and Short-Run Price Asymmetries and Hysteresis in the Italian Gasoline Market.” Energy Policy 78( March 2015):41-50.

—. "Asymmetric Asymmetries' in Eurozone Markets Gasoline Pricing." Journal of Economic Asymmetries 13( June 2016):89-99.

Barnato, K., and L. Graham. "Future of the Chocolate Industry Looks Sticky." CNBC. March 24, 2016. Internet site: http://www.cnbc.com/2016/03/24/ future-of-the-chocolate-industry-looks-sticky.html (Accessed July 21, 2017).

Burstein, A.T., and G. Gopinath. "International Prices and Exchange Rates.” National Bureau of Economic Research (NBER) Working Paper No. 18829, Cambridge, MA: NBER, 2013.

Chen, N., and L. Juvenal. "Quality, Trade, and Exchange Rate Pass-Through.” Journal of International Economics 100( May 2016):61-80.

Delatte, A.-L., and A. López-Villavicencio. "Asymmetric Exchange Rate Pass-Through: Evidence from Major Countries." Journal of Macroeconomics 34,3(2012):833-44.

Engle, R.F., and C.W.J. Granger. "Co-integration and Error Correction: Representation, Estimation, and Testing." Econometrica 55,2(1987):251-76.

Estrella, G.V. "A Review of the Dominican Cocoa Industry: Determining Advantages and Factors to Improve." Master's thesis, Department of Agricultural Economics and Agribusiness, Louisiana State University, Baton Rouge, 2016.

Federal Reserve Bank of St. Louis. "Gross Domestic Income.” Economic Research, Federal Reserve Bank of St. Louis, 2017. Internet site: https://fred.stlouisfed.org/categories/ 33122 (Accessed April 9, 2017).

Fedoseeva, S. "Are Agri-food Exports Any Special? Exchange Rate Nonlinearities in European Exports to the US." German Journal of Agricultural Economics 63,4(2014):259-70.

. "Same Currency, Different Strategies? The (Asymmetric) Role of the Exchange Rate in Shaping European Agri-food Exports." Applied Economics 48,11(2016):1005-17. 
Fedoseeva, S., and R. Zeidan. "A Dead-End Tunnel or the Light at the End of It: The Role of BRICs in European Exports. Economic Modelling 59( December 2016):237-48.

Food and Agriculture Organization of the United Nations (FAO). "FAOSTAT." FAO, 2017. Internet site: http://faostat.fao.org/default.aspx (Accessed February 3, 2017).

Fousekis, P., and E. Trachanas. "Price Transmission in the International Skim Milk Powder Markets.” Applied Economics 48,54(2016):5233-45.

Frey, G., and M. Manera. "Econometric Models of Asymmetric Price Transmission.” Journal of Economic Surveys 21,2(2007):349-415.

Gilbert, C.L. "Cocoa Market Liberalization in Retrospect." Review of Business and Economics 54,3(2009):294-312.

Jammazi, R., A. Lahiani, and D.K. Nguyen. “A Wavelet-Based Nonlinear ARDL Model for Assessing the Exchange Rate Pass-Through to Crude Oil Prices." Journal of International Financial Markets, Institutions and Money 34( January 2015):173-87.

Johansen, S. "Statistical Analysis of Cointegration Vectors." Journal of Economic Dynamics and Control 12,2-3(1988):231-54.

Kilian, L. "Exogenous Oil Supply Shocks: How Big Are They and How Much Do They Matter for the U.S. Economy?" Review of Economics and Statistics 90,2(2008):216-40.

Miljkovic, D., G.W. Brester, and J.M. Marsh. "Exchange Rate Pass-Through, Price Discrimination, and US Meat Export Prices." Applied Economics 35,6(2003): 641-50.

Miljkovic, D., and R. Zhuang. "The Exchange Rate Pass-Through into Import Prices: The Case of Japanese Meat Imports. Applied Economics 43,26(2011):3745-54.

Nelson, C.R., and C.R. Plosser. "Trends and Random Walks in Macroeconomic Time Series: Some Evidence and Implications.” Journal of Monetary Economics 10,2(1982): 139-62.

Nyemeck, J., J. Gockowski, and G.B. Nkamleu. "The Role of Credit Access in Improving Cocoa Production in West African Countries." Proceedings Second International Conference African Association of Agricultural Economists (AAAE), Accra, Ghana. Nairobi, Kenya: African Association of Agricultural Economists, 2007, pp. 215-24.

OANDA. "CFA Franc BCEAO." OANDA Corporation, 2017. Internet site: https://www. oanda.com/currency/iso-currency-codes/XOF (Accessed July 18, 2017).

Pesaran, M.H., and Y. Shin. "An Autoregressive Distributed-Lag Modelling Approach to Cointegration Analysis.” Econometric Society Monographs 31(1998):371-413.

Pesaran, M.H., Y. Shin, and R.J. Smith. "Bounds Testing Approaches to the Analysis of Level Relationships.” Journal of Applied Econometrics 16,3(2001):289-326.

Pompelli, G.K., and D.H. Pick. "Pass-Through of Exchange Rates and Tariffs in Brazil-U.S. Tobacco Trade.” American Journal of Agricultural Economics 72,3(1990):676-81.

Potts, J., M. Lynch, A. Wilkings, G. Huppé, M. Cunningham, and V. Voora. The State of Sustainability Initiatives Review 2014: Standards and the Green Economy. Technical report, Winnipeg, MB: International Institute for Sustainable Development; London: International Institute for Environment and Development, 2014.

Shin, Y., B. Yu, and M. Greenwood-Nimmo. "Modelling Asymmetric Cointegration and Dynamic Multipliers in a Nonlinear ARDL Framework.” Festschrift in Honor of Peter Schmidt. R. Sickles and W. Horrace, eds. New York: Springer, 2014, pp. 281-314.

Ton, G., G. Hagelaars, A. Laven, and S. Vellema. "Chain Governance, Sector Policies and Economic Sustainability in Cocoa: A Comparative Analysis of Ghana, Côte d'Ivoire, and Ecuador." Markets, Chains and Sustainable Development Strategy and Policy Paper No. 12. Wageningen, the Netherlands: Wageningen UR, 2008. 
Tsiboe, F., B.L. Dixon, L.L. Nalley, J.S. Popp, and J. Luckstead. "Estimating the Impact of Farmer Field Schools in sub-Saharan Africa: The Case of Cocoa." Agricultural Economics 47,3(2016):329-39.

United Nations. "UN Comtrade Database." United Nations, 2017. Internet site: http:// comtrade.un.org/ (Accessed April 11, 2017).

U.S. Department of Agriculture, Economic Research Service (USDA-ERS). "Agricultural Exchange Rate Data Set.” USDA-ERS, 2017. Internet site: https://www.ers.usda.gov/ data-products/agricultural-exchange-rate-data-set.aspx (Accessed April 6, 2017).

U.S. Department of Labor, Bureau of Labor Statistics. "Import/Export Price Indexes: MXP Databases.” U.S. Department of Labor, 2017. Internet site: https://www.bls.gov/mxp/ data.htm (Accessed April 14, 2017).

Wang, S. Examining the Effects of Dollarization on Ecuador. Washington, DC: Council on Hemispheric Affairs, 2016.

Wilcox, M.D. Jr., and P.C. Abbott. "Can Cocoa Farmer Organizations Countervail Buyer Market Power?" Paper presented at the American Agricultural Economics Association Annual Meeting, Long Beach, CA, July 23-26, 2006.

World Agroforestry Centre (ICRAF). Cocoa and Chocolate. ICRAF, 2017. Internet site: http://www.worldagroforestry.org/treesandmarkets/inaforesta/documents/cocoa\% 20and\%20chocolate/cocoa\%20and\%20chocolate.pdf (Accessed July 18, 2017).

WorldAtlas. “Top 10 Cocoa Producing Countries.” WorldAtlas, 2017. Internet site: http: //www.worldatlas.com/articles/top-10-cocoa-producing-countries.html (Accessed July 21, 2017).

Yumkella, K.K., L.J. Unnevehr, and P. Garcia. "Noncompetitive Pricing and Exchange Rate Pass-Through in Selected U.S. and Thai Rice Markets." Journal of Agricultural and Applied Economics 26,2(1994):406-16. 